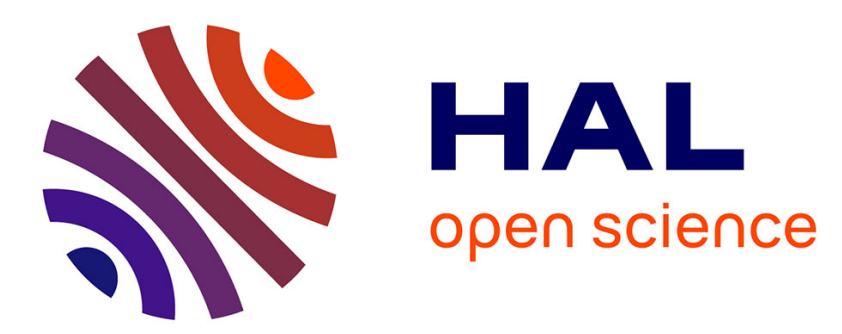

\title{
Thermo-mechanical modeling of the obduction process based on the Oman ophiolite case
}

Thibault Duretz, Philippe Agard, Philippe Yamato, Céline Ducassou, Evgenii E.B. Burov, T. V. Gerya

\section{- To cite this version:}

Thibault Duretz, Philippe Agard, Philippe Yamato, Céline Ducassou, Evgenii E.B. Burov, et al.. Thermo-mechanical modeling of the obduction process based on the Oman ophiolite case. Gondwana Research, 2016, 32, pp.1-10. 10.1016/j.gr.2015.02.002 . insu-01120232

\section{HAL Id: insu-01120232}

https://hal-insu.archives-ouvertes.fr/insu-01120232

Submitted on 9 Mar 2015

HAL is a multi-disciplinary open access archive for the deposit and dissemination of scientific research documents, whether they are published or not. The documents may come from teaching and research institutions in France or abroad, or from public or private research centers.
L'archive ouverte pluridisciplinaire HAL, est destinée au dépôt et à la diffusion de documents scientifiques de niveau recherche, publiés ou non, émanant des établissements d'enseignement et de recherche français ou étrangers, des laboratoires publics ou privés. 


\section{Thermo-mechanical modeling of the obduction process based on}

\section{the Oman ophiolite case}

Thibault Duretz ${ }^{1,2}$, Philippe Agard ${ }^{2}$, Philippe Yamato ${ }^{3}$, Céline Ducassou ${ }^{4}$, Evguenii B.

Burov $^{2}$, Taras V. Gerya ${ }^{5}$

${ }^{1}$ Institut des sciences de la Terre, University of Lausanne, 1015 Lausanne, Switzerland

${ }^{2}$ ISTEP, UMR CNRS 7193, UPMC Sorbonne Universités, 75252 Cedex 05, Paris, France

${ }^{3}$ Geosciences Rennes, UMR CNRS 6118, Université de Rennes 1, 35042 Rennes Cedex, France

${ }^{4}$ Applied Geosciences, GUtech, PO Box 1816, Athaibah, PC 130, Sultanate of Oman

${ }^{5}$ Institute of Geophysics, ETH Zürich, Sonneggstrasse 5, 8092 Zürich, Switzerland

submission to - Gondwana Research

Keywords: Obduction; Oman; numerical modeling 


\begin{abstract}
Obduction emplaces regional-scale fragments of oceanic lithosphere (ophiolites) over continental lithosphere margins of much lower density. For this reason, the mechanisms responsible for obduction remain enigmatic in the framework of plate tectonics. We present two-dimensional (2D) thermo-mechanical models of obduction and investigate possible dynamics and physical controls of this process. Model geometry and boundary conditions are based on available geological and geochronological data and numerical modeling results are validated against petrological and structural observations of the Oman (Semail) Ophiolite. Our model reproduces the stages of oceanic subduction initiation away from the Arabian margin, the emplacement of the Oman Ophiolite on top of it, and the domal exhumation of the metamorphosed margin through the ophiolitic nappe. A systematic study indicates that $350-400 \mathrm{~km}$ of bulk shortening provides the best fit for both the maximum Pressure-Temperature conditions of the metamorphosed margin $\left(1.5-2.5 \mathrm{GPa} / 450-600^{\circ} \mathrm{C}\right)$ and the dimension of the ophiolitic nappe ( $170 \mathrm{~km}$ width). Our results confirm that a thermal anomaly located close to the Arabian margin $(\sim 100 \mathrm{~km})$ is needed to initiate obduction. We further suggest that a strong continental basement rheology is a prerequisite for ophiolite emplacement.
\end{abstract}




\section{Introduction}

Obduction remains a mysterious process with respect to why, how and where it develops. Obduction emplaces unmetamorphosed fragments of dense, oceanic lithosphere (ophiolites) atop light continental ones over distances of several hundred kilometres. Such large-scale ophiolite exposures can be found in Oman, Turkey, Newfoundland, New Caledonia, Papua New Guinea [Monié and Agard, 2009 and references therein; Cluzel et al., 2001; Lus et al., 2004; Pubellier et al., 2004]. However, compared to subduction or collision, obduction is a relatively infrequent mode of convergence, apparently transient (i.e. $<\sim 10-15 \mathrm{My}$ ) yet recurrent through time [Nicolas, 1989; Agard et al., 2007 and references therein]. One obvious possible explanation could be that obduction is rare only because of a seldom realized, particularly restrictive set of necessary boundary conditions.

Previous interpretations on how obduction proceeds are of two main types and comprise (1) thrusting of ophiolite onto the continent [flake tectonics; Oxburgh, 1972; Dewey, 1976] or (2) continental subduction beneath oceanic lithosphere following subduction initiation [Michard et al., 1984; Figure 1a]. Tethyan-style ophiolites [Moores, 1982] are indeed characterized by the presence of metamorphosed high-pressure low-temperature (HP-LT) continental units exposed in tectonic windows below the ophiolite [Searle and Malpas, 1980] and of a high-temperature (HT) amphibolitic to granulitic metamorphic sole welded to the base of the ophiolite. HT soles predate ophiolite emplacement on continental domains and are interpreted as remnants of obduction initiation [Jamieson, 1986; Boudier et al., 1988]. HP continental metamorphism is coeval with the underthrusting of the continental lithosphere beneath the ophiolite. In the second 
interpretation, ophiolite emplacement (i.e., its juxtaposition onto the continent as a 'passive' lid) is mechanically tied to the exhumation of the HP continental rocks [Agard et al., 2007].

Conceptual models of obduction initiation either involve mid-ocean ridges [Le Pichon and Nicolas, 1981; Boudier et al., 1985, 1988] or transform faults [Hacker et al., 1996, Breton et al., 2004]. Although exact initiation sites remain debated [e.g., Rioux et al., 2013], models have to take into account that oceanic lithosphere is thermally young during obduction initiation, in particular to conform to the HT conditions recorded by metamorphic soles [Hacker, 1994]. This also implies that such lithosphere is mechanically weak [e.g., Burov, 2011] and hence can be relatively easily deformed.

Since obduction mechanisms remain actively debated, we hereby develop and systematically investigate thermo-mechanical models of ophiolite emplacement. Our regional-scale modeling shows that the proposed conceptual models are thermo-mechanically feasible under a number of reasonable assumptions on the rheological properties and thermal structure of the interacting lithospheric units. We assess the validity of the models by comparing their results to first order geological features of the Oman Ophiolite and of the underlying Arabian continental margin (PT histories, dimensions, geometries and timescales; Figure 1). We also show that the developed models can be used to constrain additional kinematic and rheological parameters.

\section{Geological Constraints From the Oman Setting}

The goal of this study is not only to develop a model explaining Oman Ophiolite emplacement but also to characterize the key parameters involved in the obduction process. For this, we need to find natural constraints that could be used to test (validate or invalidate) the model results. The 
first order constraints used in our study are based the well-studied Oman case, and can be summarized as follow:

(1) Final morphology of the ophiolite. The overall structure of the Oman Mountains and crust is well documented by structural data and geophysical data [Al Lazki et al., 2002]. The ophiolite length atop the continental margin is of $\sim 150-200 \mathrm{~km}$ and the ophiolite sequence characterized by a thickness of 0 to $15 \mathrm{~km}$ (see Figures $1 \mathrm{~b}$ and $1 \mathrm{c}$ ). Too short ophiolite nappe propagation on top of the passive margin or too limited thinning of the oceanic lithosphere will thus be a first order criterion to invalidate a model.

(2) Nappes stacking and reconstitution of the Arabian margin: The ophiolite emplacement is characterized by nappe stacking of different units structurally delimited by tectonic contacts (Figures $1 \mathrm{~b}$ and $1 \mathrm{c}$ ). From top to bottom, the Allochthonous units consists of the Samail Nappe (ophiolite sequence) underlain by a thin tectonic high-temperature metamorphic sole and located on top of the Hawasina nappes (slope to basin sedimentary rocks initially deposited north-east of the Arabian platform from Permian to Cretaceous times), themselves thrusted onto autochtonous units (the so-called "Autochthonous A" consisting of Proterozoic to Palaeozoic sedimentary sequences unconformably overlain by the "Autochthonous B", mainly made of Permian to Cretaceous shelf carbonates) [Breton et al., 2004; Glennie et al., 1974; Searle, 2007]. The Hawasina basin was located at the tip of Arabia and underlain by thinned Arabian continental crust and/or continent to ocean transitional material [Béchennec et al., 1990 and references therein)]. Restoration of the Hawasina nappes suggests a minimum of $300 \mathrm{~km}$ of shortening, which places strong constraints on minimum amounts of convergence in the model. The autochthonous units are strongly deformed and metamorphosed in the northeastern part of Oman where they crop out as the high-pressure low-temperature (HP-LT) Saih Hatat metamorphic 
dome [Michard et al., 1984; Yamato et al., 2007b; Agard et al., 2010; Figure 1b and 1c]. This nappe stack is unconformably overlain by the Post-Nappes Autochthonous units, which consist of sedimentary deposits ranging in age from Late Cretaceous [Nolan et al., 1990; Abbasi et al., 2014] to Quaternary. The Late Cretaceous to Mid-Miocene sediments are affected by a Miocene to Oligocene deformation phase [Zagros phase: Saddiqi et al., 2006; Searle, 2007] at the origin of an important uplift in the the Jabal Akhdar and the Saih Hatat domes.

(3) Syn-obduction sedimentation: The maximum thickness of syn-obduction, "foreland" sediments is recorded in front of the ophiolite nappe (Coniacian to Maastrichtian Fiqa Formation) [Forbes et al., 2010], where it reaches 1-3.5 km [1.35 km in Al-Lazki et al. 2002; > $1.5 \mathrm{~km}$ in Boote et al., 1989 and $3.5 \mathrm{~km}$ in Ravault et al., 1997]. However the thickness of syntectonic sediments below the nappes (Turonian to Santonian; Muti Formation) does not exceed a few tens to a few hundred of meters [Rabu, 1988; Le Métour, 1988]. This also constitutes an import point allowing us to discuss the validity of a model.

(4) P-T-t paths (see Figure 1d). P-T-t paths are considered as key constraints to validate or invalidate a model in addition to the overall final structure. Such constraints have been successfully used in the past [e.g. Gerya et al., 2002; Yamato et al., 2007a, 2008; Warren et al., 2008]. They indeed allow checking the model evolution through time and not only the final deformation. In the Oman case, as below all large-scale obducted ophiolites, the existence of the HP-LT metamorphic dome and of the HT metamorphic sole found beneath the ophiolite should be accounted for, and the burial/exhumation of the continental passive margin confronted with the P-T-t evolution as shown in Figure 1d.

\section{Model setup}


We use the thermo-mechanically coupled visco-plastic 2D code I2VIS [Gerya \& Yuen, 2003], which is based on a combination of a finite difference method, applied on a staggered Eulerian grid, and a marker-in-cell technique. The momentum, continuity and energy equations are solved on the Eulerian frame. Lagrangian markers move according to velocity field obtained on the fixed grid and carry physical properties as well as pressure and temperature throughout the model domain. Surface processes are taken into consideration by gross-scale erosion law taking into account fixed erosion and sedimentation rates $\left(1 \mathrm{~mm} \cdot \mathrm{yr}^{-1}\right)$.

\subsection{Initial Geometry and thermal Structure}

The material properties used in our thermomechanical modeling experiments can be found in Table 1 and their initial geometries are presented in Figure 2. Our model design is built around a number of key observations that pertain to the Oman realm:

The classic, well-preserved Oman Ophiolite (Penrose conference, 1972) belongs to the Late Cretaceous Peri-Arabic obduction event, which affected the Neotethys almost synchronously along thousands of km from Turkey to Oman [< 5 My; Ricou, 1971; Agard et al., 2007; Monié and Agard, 2009]. The Neotethyan oceanic lithosphere first formed as a result of Permo-Triassic rifting [Lippard et al., 1986; Chauvet et al., 2009]. Despite numerous studies devoted to oceanic lithosphere formation [Nicolas et al., 2000; Shervais, 2001; Le Mee et al., 2004], the exact nature and original setting of the Oman Ophiolite is still a matter of debate, with evidence for both ocean basin formation and supra-subduction geochemical imprints [Pearce et al., 1981; Nicolas et al., 2000; Shervais, 2001; Godard et al., 2003; McLeod et al., 2013; Rioux et al., 2013]. However, whatever its exact petro-geodynamic setting, (1) the 96.4 to $95.5 \mathrm{Ma}$ on-axis igneous ages of the obducted Oman Ophiolite [Rioux et al., 2012, 2013] and (2) the 95 Ma plagiogranite 
dykes cross-cutting the ophiolite [Tilton et al., 1981] show that the Oman ophiolite was a piece of young oceanic lithosphere formed during the late Cretaceous within a much older, at least early Mesozoic, Neotethyan lithosphere.

Whatever its exact setting, the Oman Ophiolite was thermally and magmatically young $[<10$ My, e.g. Hacker, 1994] at the time of its emplacement. Based on the amount of shortening of the Hawasina nappes, constraints on obduction duration and Neotethyan kinematics at the time, the corresponding oceanic domain was formed relatively close to the Arabian continental margin [i.e., no more than 300-400 km away; Searle and Cox, 1999], probably in response to regional scale geodynamic reorganization [ 115 Ma; Agard et al., 2007].

We therefore herein focus on the likely scenario of subduction/obduction initiation in a young, hot oceanic domain (taken as a proxy for the young oceanic lithosphere obducted in Oman, as discussed above) located in the vicinity of a continental passive margin (i.e., Arabia), followed by short-lived continental subduction.

In the model, we define this hot oceanic domain by a temperature anomaly within the oceanic plate (Figure 2). Such temperature anomaly represents mechanically weak oceanic lithosphere and thus either corresponds to a ridge or back-arc setting. The position of this anomaly with regard to the OCT $\left(d_{O C T}\right)$ will hence control the location of obduction initiation. In our reference model, we located the center of the anomaly $100 \mathrm{~km}(x=1800 \mathrm{~km})$ away from the oceancontinent transition (OCT). The length of the OCT is $100 \mathrm{~km}$. Within this domain crustal thickness linearly decreases from $35 \mathrm{~km}$ to $7 \mathrm{~km}$ and the thermal structure progressively evolves from a continental geotherm $\left(15^{\circ} \mathrm{C} / \mathrm{km}\right)$ to a an oceanic geotherm (thermal age $\left.\tau=80 \mathrm{Ma}\right)$. The 
thermal age of the rightmost oceanic plate (i.e., future ophiolite) linearly varies from 0 to $80 \mathrm{Ma}$ away from this thermal anomaly $(x=2600 \mathrm{~km}$, Figure 2$)$ simulating a spreading rate $(\gamma)$ of 1 cm. $\mathrm{yr}^{-1}$. Crustal thickness of the oceanic lithosphere is set to $7 \mathrm{~km}$, accounting for a fast spreading ridge setting with voluminous crustal production [Boudier et al., 1988].

\subsection{Time-dependent Boundary Conditions}

We first impose far-field compression plate kinematics with a total convergence velocity $\left(V_{\text {comp }}\right)$ of $4 \mathrm{~cm} \cdot \mathrm{yr}^{-1}$. A 10 My period of compression and subduction is indeed required between subduction initiation, constrained at 96-95 Ma by radiometric data on HT metamorphic soles [Hacker, 1991, 1994; Rioux et al., 2013], and peak HP-LT metamorphism of the Arabian continental margin at 82-79 Ma [Warren et al., 2003, 2005; Gray et al., 2004]. Far-field extension, through a linear decrease of the convergence rate (from $V_{\text {comp }}=4 \mathrm{~cm} . \mathbf{y r}^{-1}$ to $V_{\text {ext }}=-1$ cm. $\mathrm{yr}^{-1}$ within $1 \mathrm{My}$ ), is then applied to account for the resumption of subduction beneath Eurasia [Monié \& Agard, 2009], for the likely slab detachment beneath Oman [Chemenda et al., 1996] and for expulsion-like exhumation of HP-LT rocks [Agard et al., 2010].

\section{Model Results}

\subsection{Reference model}

Our reference model assumes a bulk shortening $(d x)$ of $400 \mathrm{~km}$ during the first $10 \mathrm{My}$ of the model. The onset of compressional tectonics is responsible for the inversion of the proximal young oceanic basin. As a result, subduction localizes at the thermal anomaly with an orientation dictated by the initial asymmetry of the thermal structure (Figure 3). HT conditions attributable to the metamorphic sole are reached within 1.5 My after subduction initiation (Figure 3). After 4 
My of oceanic subduction, further compression leads to the underthrusting of the continental margin and, consequently, to the passive emplacement of oceanic lithosphere above the continent (Figure 3). After $10 \mathrm{My}$ of compression, P-T conditions of $1.5-2.5 \mathrm{GPa} / 450-600^{\circ} \mathrm{C}$ are reached along the upper crust of the continental slab.

Following the inception of extension (at $11 \mathrm{My}$ ), stress transfer through the strongly coupled subduction interface enables the deformation of the ophiolitic upper plate. Thinning of the obducted oceanic lithosphere takes place coevally with the exhumation of the buried continental margin. With ongoing extension (after $10 \mathrm{My}$ ), the subducted crust is exhumed beneath the ophiolite, resulting in the formation of a large metamorphic dome. No significant internal deformation is observed in the buried crust and HP rocks exhibiting different peak metamorphic conditions are exhumed in a coherent fashion [plate eduction; Duretz et al., 2012]. Note that model resolution does not allow to track complex deformation of the thin meta-sedimentary units on top of the autochthonous pile (e.g., Searle et al., 2004; Agard et al., 2010). Exhumation lasts about $15 \mathrm{My}$ and results in retrograde paths that are close to adiabatic during the first $\sim 10 \mathrm{My}$ ( -4 ${ }^{\circ} \mathrm{C} / \mathrm{My}$ ). Further erosion results in the development of tectonic windows and brings rocks to the surface. The surface extent of the ophiolite nappe is $\sim 170 \mathrm{~km}$ and its thickness varies between 5 and $15 \mathrm{~km}$. HP-LT metamorphic domes develop in the exhumed margin with a wavelength of $\sim 30 \mathrm{~km}$.

\subsection{Model validation: Case of the Oman Ophiolite}

This model successfully reproduces a number of key features of the Oman obduction (see section 2).

(1) Characteristic dimensions and geometries of the Oman (or Semail) Ophiolite: 
A specific feature of our model is its ability to reproduce an ophiolitic nappe with dimensions comparable to nature [i.e., $\sim 150 \mathrm{~km}$, Searle et al., 2004] atop the underthrusted continental margin. The final structural thickness of the model's ophiolite varies between 0 and $15 \mathrm{~km}$, hence matching the thickness of the Oman Ophiolite [Glennie et al., 1974; Ceuleneer et al., 1988]. Although the model's ophiolite thickness reaches more than $30 \mathrm{~km}$ during overthrusting, significant thinning occurs during the exhumation stage. Such results are obtained if a period of far-field extension, after $10 \mathrm{My}$ in our model, accompanies ophiolite emplacement, which accords with the resumption of efficient subduction beneath Eurasia after $85 \mathrm{Ma}$ [Monié and Agard, 2009] and field evidence of extension during the latest obduction stages [Fournier et al., 2006]. The obducted lithospheric section comprises fragments of oceanic crust, together with serpentinized and pristine mantle. Our reference model also reproduces a characteristic structural relationship between the ophiolite and the metamorphosed continental margin, with the formation of the Saih Hatat dome [Michard et al., 1984].

(2) Pressure-Temperature-time evolution:

Modeled P-T conditions of the metamorphic sole at $\sim 1 \mathrm{GPa} / 750^{\circ} \mathrm{C}$ are short-lived $(<2 \mathrm{My})$ and match petrological data and previous thermal models [e.g., Hacker, 1991], both in terms of duration [<1-2 My; Hacker, 1994; Hacker et al., 1996; Searle and Cox, 1999; Warren et al., 2005; Rioux et al., 2013] and P-T estimates [0.8-1 GPa, 700-800 ${ }^{\circ} \mathrm{C}$ on average; Gnos, 1998]. PT conditions inferred for the subducted continental HP-LT metamorphic rocks match remarkably well natural occurrences (Figure 2), either for low-grade blueschist facies [1 GPa / 300 ${ }^{\circ}$; Agard et al., 2010], high-grade blueschist [from 1-1.2 $\mathrm{GPa} / 350^{\circ} \mathrm{C}$ to $0.8 \mathrm{GPa} / 450-470^{\circ} \mathrm{C}$; Yamato et al., 2007b] or eclogite facies conditions [2-2.3 GPa / 550 ${ }^{\circ} \mathrm{C}$; Searle et al., 2004; Warren and Waters, 2006]. The calculated metamorphic gradient along prograde paths is comprised between 
$8-10^{\circ} \mathrm{C} / \mathrm{km}$, which is consistent with natural record of short-lived continental subduction [Agard and Vitale-Brovarone, 2013].

(3) Plate kinematics and emplacement model:

The relative timing of oceanic thrusting and HP-LT peak metamorphism is largely prescribed by the choice of plate kinematics from available geological data (see Model setup section, above). In our model the timing of retrograde metamorphism, showing that HP-LT rocks are largely exhumed after 22 My after the onset of compression (Figure 2), fits particularly well available fission-track data [i.e., 70-75 Ma; Saddiqi et al., 2006]. The final domal exhumation associated with erosion and thinning of the obducted ophiolite mantle contributes to realistic ophiolite thickness. In our model, the ophiolite is thus emplaced passively on the continental margin through continental underthrusting [Searle and Malpas, 1980; Yamato et al., 2007b; Lagabrielle et al., 2013].

\section{(4) Structures and sedimentation:}

As described above (in section 2), field evidence shows that the nappes stack consists of (from bottom to top): the autochthonous units topped by very thin $(<\mathrm{km})$ syn-obduction sediments, the Hawasina nappes, and the ophiolitic sequence (oceanic crust and mantle, underlain by the metamorphic sole). Because of their thickness (a few hundred meters only), the Hawasina nappes could not be modeled (below the spatial resolution of our model). In the model, the few syntectonic sediments produced by the erosion of both the ophiolitic nappe and the Arabian platform are mainly deposited in front of the advancing nappes and progressively migrating towards the continent. The first (oldest) deposits are progressively dragged at various depths in the subduction zone (from shallow depths down to $\sim 30 \mathrm{~km}$ ). As a result, after $30 \mathrm{My}$, the sediments preserved below the nappes are relatively thin or even absent where the metamorphic dome is 
formed. The thickest sequence, corresponding to the latest (youngest) syn-obduction deposits, is located in front of the nappes and has not been dragged in the subduction zone. Exhumation of metamorphic rocks occurs simultaneously with the sedimentation on top of the ophiolitic nappes. These results are consistent with the geological data. Indeed, the oldest syn-obduction deposits [Muti Formation of Turonian to Santonian age, Rabu et al., 1990] are preserved below the nappes and has been affected by various degrees of metamorphism [increasing from SW to NE, Le Métour et al., 1990], while the youngest deposits [Fiqa Formation of Coniacian to Maastrichtian age, Forbes et al. 2010] are located further south. The maximum thickness of syntectonic sediments ( 3 to $4 \mathrm{~km}$ ) in front of the nappes fits the maximum thickness of the synobduction Fiqa Formation obtained from sub-surface data $[1.5 \mathrm{~km}$ to $3.5 \mathrm{~km}$, Al-Lazki et al. 2002; Boote et al. 1990; Ravault et al., 1997]. The amount of sediments below the nappes might be slightly over-estimated ( 1 km instead of the few hundred meters observed in the field). However these differences are negligible considering the numerical resolution of the model and the amount of sedimentation is relatively low compared to other models (see sections 4.3.3 and 4.3.4). The distance between these thick syn-tectonic sediments and the metamorphic dome $(\sim 200 \mathrm{~km})$ in the model fits with the distance between the depocenter of the Fiqa (Suneinah) basin and the Sail Hatat dome [Boote et al., 1990]. Last, sedimentation on top of the ophiolitic nappe starting as soon as Late Cretaceous [Qahlat Formation, Nolan et al., 1990; Abbasi et al., 2014] is then contemporaneous with the final exhumation of metamorphic rocks and the formation of the Saih Hatat dome [75 to 70 Ma; Saddiqi et al., 2006].

\subsection{Sensitivity of obduction process to model parameters}


The merits and the sensitivity of the model's results to variable parameters are discussed in the following section.

\subsubsection{Amount of convergence}

As outlined above, available metamorphic age datings place strong constraints on the time interval between subduction initiation and burial of the continental margin ( 10 My). The convergence rate across the newly formed subduction zone, however, and consequently the amount of relative plate convergence, remains poorly constrained [Ricou, 1994; Barrier and Vrielynck, 2008]. We thus tested the influence of the amount of compression on the final result. Figure 4 compares the results of all models at their final stage (30 My) for models that underwent variable amounts of bulk shortening (from $d x=300 \mathrm{~km}$ to $d x=450 \mathrm{~km}$ ). The models display a roughly linear dependency between the main obduction parameters, namely maximum pressure-temperature conditions and ophiolitic nappe width. Maximum pressure and temperature conditions range from $1.5 \mathrm{GPa} / 550^{\circ} \mathrm{C}$ for $\mathrm{dx}=300 \mathrm{~km}$ up to $3.5 \mathrm{GPa} / 800^{\circ} \mathrm{C}$ with $\mathrm{dx}=450$ $\mathrm{km}$. Similarly, the width of the obducted ophiolite linearly increases from $\sim 120 \mathrm{~km}$ to $\sim 220 \mathrm{~km}$. Varying the convergence rate, however, does not notably affect the thickness of the ophiolite. A bulk shortening between 350 and $400 \mathrm{~km}$ (Figure 4) yields the most realistic P-T range in the exhumed continental margin.

\subsubsection{Continental basement rheology}

The rheology of the continental basement represents another key parameter for obduction. We have explored the sensitivity of the reference model to four types of rheological layering. The 
weakest crustal model consists of Wet Granite (Ranalli, 1995) upper and lower crust, whereas the strongest is represented by felsic granulite (Ranalli, 1995). Upper/lower crust rheological stratifications (strong/weak and weak/strong) using similar flow laws were also tested. Figure 5 depicts material configurations (after 25 My of model time) obtained using the different rheological models and a shortening of $400 \mathrm{~km}$. The weakest crust end-member is subjected to homogeneous thickening (Figure 5a), which limits the thrusting of oceanic units above the continent. In the weak/strong crust model, the deformation is decoupled. As the lower crust subducts, the upper crust thickens resulting in a reduced ophiolitic nappe (Figure 5b). A strong/weak crustal model localizes extensional deformation by necking of the upper crust (Figure 5c), inhibiting the preservation of the ophiolite. Only the strongest crust end-member allows for the overthrusting of the oceanic plate and the preservation of the ophiolite during the extension phase (Figure 5d). These results clearly indicate that a strong continental basement rheology, which minimizes the strength contrast between the oceanic and continental crust, is a necessary condition for ophiolite emplacement.

\subsubsection{Thermal anomaly location}

Available geochronological data provide constrains concerning the distance that was separating the location of initiation obduction and the Arabian OCT. It is however difficult to accurately evaluate the location of obduction initiation. For this reason, we tested the influence of the thermal anomaly location using our reference model. The distance that separates the OCT from the center of the thermal anomaly is referred to as $d_{O C T}$. As the compression duration is fixed to $10 \mathrm{My}$, total shortening and compression rates will subsequently vary with $d_{O C T}$. We first considered the case where $d_{O C T}=50 \mathrm{~km}\left(d x=350 \mathrm{~km}, V_{\text {comp }}=3.5 \mathrm{~cm} . \mathbf{y r}^{-1}\right.$; Figure 6a). Such 
setting is equivalent to the reference model (Figure 6b) since neither the dimensions of the ophiolite nor the crustal structures are changed. Considering thermal anomalies located at $d_{O C T}=$ $200 \mathrm{~km}\left(\mathrm{dx}=500 \mathrm{~km}, \mathrm{~V}_{\text {comp }}=5 \mathrm{~cm} \cdot \mathbf{y r}^{-1}\right.$, Figure 6c $)$ and $d_{O C T}=300 \mathrm{~km}\left(d x=600 \mathrm{~km}, V_{\text {comp }}=\right.$ $6.00 \mathrm{~cm} . \mathbf{y r}^{-1}$, Figure 6d) leads to drastically different results. For $d_{O C T}$ equal or larger than 200 $\mathrm{km}$, slab pull generated by the subduction of the oceanic plate leads to enhanced subducting plate deflection. A longer period of oceanic subduction favors the development of an accretionary wedge, which further inhibits the emplacement of the ophiolite on the continental plate. Moreover, the presence of very thick syn-subduction sedimentary sequences $(\sim 50 \mathrm{~km})$ an exhumation throughout the upper plate in these models is inconsistent with field observations in Oman (See Sec. 4.2).

\subsubsection{Thermal anomaly intensity}

In order to investigate the model sensitivity to the intensity of the thermal anomaly, we have varied the spreading rate correspond to the hot oceanic domain $(\gamma)$. This parameter controls the thermal structure of the right oceanic plate, which will potentially be subjected to obduction. The colder model is characterized by a $\gamma=0.5 \mathrm{~cm} . \mathbf{y r}^{-1}$ (Figure 7a). The upper plate is thus thicker, stronger and denser than in the reference model (Figure 7b). In such setting, enhanced subduction erosion leads to the development of a thick sedimentary pile at the plate interface, which greatly reduces the possibility of ophiolite emplacement and is not supported by field and subsurface data (see Sec. 4.2). In contrast, the hotter ocean model $\left(\gamma=2.0 \mathrm{~cm} . \mathbf{y r}^{-1}\right)$ allows the development of ophiolite obduction. A hotter structure induces more internal deformation (thickening) within the ophiolitic nappe. As a result, the final width of the ophiolite is reduced by about $50 \mathrm{~km}$ compared to the reference model. The exhumation of the continental margin 
through the ophiolite (doming) also occurs earlier, as it is facilitated by the hotter structure of the oceanic plate.

\subsubsection{Timing of compression to far-field extension transition}

The compression duration is well constrained by the geological record of Oman $(\sim 10 \mathrm{My}$, see Sec. 2.1). We nevertheless tested the model's sensitivity to the compression duration $\left(\Delta t_{\text {comp }}\right)$, while keeping the total amount of shortening constant $(d x=400 \mathrm{~km})$. Figure 8 depicts models geometries obtained with $\Delta t_{\text {comp }}$ varying from 5 My $\left(V_{\text {comp }}=8.0 \mathrm{~cm} \cdot \mathbf{y r}^{-1}\right.$, Figure $\left.8 \mathrm{a}\right)$ to $15 \mathrm{My}$ $\left(V_{\text {comp }}=2.66 \mathrm{~cm} \cdot \mathbf{y r}^{-1}\right.$, Figure $\left.8 \mathrm{c}\right)$. Our results indicate that this parameter does not significantly influence obduction dynamics. After 25 My of model time, final model geometries are indeed similar to the reference model (Figure 8b), except for the amount of mantle thinning.

\subsubsection{Impact of far-field extension}

The occurrence of far-field extension after obduction [as suggested by the resumption of efficient subduction beneath Zagros, Monié \& Agard, 2009; Agard et al., 2011] is an important element of our reference model. We thus tested the influence of such kinematic forcing, while maintaining similar compressional history $(d x=400 \mathrm{~km}$ during $10 \mathrm{My})$. Firstly, we considered the case where no kinematic extensional constraints are applied after compression. In such setting, the plate boundary is let free to rebound in response to buoyancy force readjustment [i.e. plate eduction, Duretz et al., 2012]. During the compression stage, the lack of significant sedimentary input entering the subduction plate interface, which is consequently strongly coupled, inhibits any dynamic plate rebound (Figure 9a). Models subjected to kinematic extension $\left(V_{\text {ext }}\right.$ ) of 0.5 $\mathrm{cm} . \mathbf{y r}^{-1}$ and $2.0 \mathrm{~cm} . \mathbf{y r}^{-1}$ were investigated. Our results suggest that far-field extension rates only 
have a limited impact on the dimension of the ophiolite nappe. Slower rates seem to favor crustal exhumation (Figure 9b). This effect is apparent since the experiments were stopped at different model times (but for the same amount of extension): for the slowest case $\left(V_{e x t}=0.5 \mathrm{My}\right.$, Figure 9b) buoyant emplacement of the continental dome has thus more time to develop than in faster

cases (Figures 9c, 9d). In our visco-plastic models, materials can be subjected to both ductile and brittle deformation. In our model, late orogenic extension is responsible for extensional ductile deformation in the exhumed continental margin. The overlying ophiolite, which consists of relatively stronger lithologies (mafic and ultramafic), undergoes normal faulting. This is in good agreement with field data documenting extensional shears and normal faults in the exhumed continental margin as well as high and low normal faults within the overlying ophiolite and metamorphic sole [Michard et al., 1994; Gray and Gregory, 2010; Al Wardi and Butler, 2007; Gomez-Rivas et al., 2014].

\section{Discussion}

Results obtained from both our reference model and the parametric study show that a number of physical parameters are crucial for enabling the ophiolite emplacement process. The required conditions are: (i) a shortening of 350 - $400 \mathrm{~km}$, (ii) the involvement of a strong continental crust and (iii) the presence of a thermal anomaly both close to the passive margin (no more than 100 $\mathrm{km}$ ) and intense (young thermal ages, equivalent to oceanic lithosphere < 0-5 My).

Further modeling should systematically explore the range of parameters favorable to obduction (i.e., rheology, velocities, range of coupling conditions required to promote intraoceanic 
subduction) and help to constrain triggering mechanisms [e.g., Agard et al., 2007, 2014]. Models should in particular take into account regional-scale plate kinematics on a larger scale (including convergence partitioning between existing subduction zones and incipient obduction) and consider the role of far-field tectonics in a more self-consistent way than was done here (i.e., by decreasing convergence and adding extension).

In this study, we only considered the case of subduction initiation (and therefore obduction initiation) induced by far-field push at a pre-existing thermal anomaly. However, subduction could possibly initiate in a spontaneous manner [Stern, 2004], when a sufficiently large buoyancy contrast exists between tectonic plates [e.g., Marques et al., 2013]. Other geological settings might be considered for obduction/subduction initiation in the vicinity of a passive margin, such as pre-existing vertical fracture zones [Gurnis et al., 2004] or dipping fault zones [Toth and Gurnis, 1998]. The presence of a thermal anomaly in the oceanic plate is nevertheless a key element in order to match the HT conditions retrieved from metamorphic soles [Jamieson, 1986; Hacker, 1990]. Our numerical experiments predict metamorphic sole temperatures that are slightly colder than those estimated in the Oman metamorphic sole [i.e., within uncertainties yet 50-100 ${ }^{\circ} \mathrm{C}$ colder; Searle and Cox, 1999]. Here, we did not investigate the influence of the strength of the oceanic lithospheric layers. It should however strongly control the amount of shear heating [Brun and Cobbold, 1980; Duprat-Oualid et al., 2013] produced during oceanic yielding and thrusting. As shear heating potentially plays a key role in the development of subduction [Thielmann et al., 2013], it might as well facilitate the development of metamorphic soles. Detailed thermo-mechanical models of ophiolite generation at the scale of the oceanic lithosphere are therefore needed to understand the formation of metamorphic soles. 
Similarly, due to limited spatial resolution, our model partially reproduces the sedimentary history recorded on the Arabian platform during the obduction of the Oman Ophiolite. In consequence, precise location and timing of migration of the forebulge (large wavelengh but low amplitude) and the detailed sedimentary architechture described, for instance, in Warburton et al. [1990] and Al Lazki et al. [2002] are not discussed in this paper. Despite its role for reconstructing the paleogeography of the Arabian margin [Béchennec et al., 1990], the inversion of the Hawasina basin could not be taken into account. Further high resolution models emcompassing a more realistic paleogeography may bring more insights into the dynamics of tectono-sedimentary processes associated with obduction.

\section{Conclusions}

We investigated the dynamics of obduction using $2 \mathrm{D}$ thermo-mechanical numerical models. The reference numerical model, whose set-up and boundary conditions were designed using available geological/geodynamic data from the Oman ophiolite, is validated against petrological and structural observations. We show that the compression of a thermal anomaly related to proximal oceanic magmatism can result in subduction initiation, eventually leading to obduction and ophiolite emplacement. Our results show that obduction is stable in a broad physical parameter range and does not require unusual plate kinematics. Key ingredients of obduction reside in the initial lithospheric structure and long-term plate dynamics: (1) the emplacement of ophiolitic nappes requires a strong continental basement rheology, and (2) net extension due to far-field plate reorganization is essential for the thinning of the ophiolite nappe and the formation of metamorphic domes. Our model also allows constraining the amount of convergence 
accommodated in Oman $(\sim 400 \mathrm{~km})$ and the locus of obduction initiation $(<200 \mathrm{~km}$ from the OCT).

\section{ACKNOWLEDGMENTS}

Author T. D. and the Ulysse cluster were funded through the ANR project O:NLAP. Numerical models were run on the Ulysse (ISTEP, Paris) and (ETH, Zurich) Brutus clusters. 


\section{REFERENCES CITED}

Abbasi, I. A., Hersi, O. S. and Al-Harty, A., 2014, Late Cretaceous conglomerates of the Qahlah Formation, north Oman, in: Rollinson, H. R., Searle, M. P., Abbasi, I. A., Al-Lazki, A. \& Al Kindi, M. H. (eds.), Tectonic Evolution of the Oman Mountains, Geological Society, London, Special Publications, v.392, p. 325-341.

Agard, P., Jolivet, L., Vrielynck B., Burov, E., and Monié, P., 2007, Plate acceleration: The obduction trigger? : Earth and Planetary Science Letters, v. 258, p. 428-441.

Agard, P., Searle, M., Alsop, I., and Dubacq, B., 2010, Crustal stacking and expulsion tectonics during continental subduction: P-T deformation constraints from Oman, Tectonics, v. 29, TC5018.

Agard P., Zuo, X., Funiciello, F., Bellahsen, N., Faccenna, C., Savva D., 2014, Obduction: why, how and where. Clues from analog models, Earth and Planetary Sciences, v. 393, p. 132-145.

Agard P., and Vitale-Brovarone, A., 2013. Thermal regime of continental subduction: the record from exhumed HP-LT terranes (New Caledonia, Oman, Corsica), Tectonophysics, 601, p. 206215.

Al Lazki, A. I., Seber, D., Sandvol, E., and Barazangi, M., 2002, A crustal transect across the Oman mountains, GeoArabia, v. 7, n. 1, p. 47-78.

Al-Wardi, M., Butler, R. W. H., 2007, Constrictional extensional tectonics in the northern Oman mountains, its role in culmination development and the exhumation of the subducted Arabian continental margin, Geological Society of London, Special Publication, v. 207, p. 187-202. 
Béchennec, F., Le Métour, J., Rabu, D., Bourdillon-de-Grissac, Ch., De Wever, P., Beurrier, M.,Villey, M., 1990, The Hawasina Nappes: stratigraphy, palaeogeography and structural evolution of a fragment of the south-Tethyan passive continental margin, Geological Society Special Publication, v. 49, p. 213-223

Boote, D.R.D., Mou, D. and Waite, R.I., 1990, Structural evolution of the Suneinah Foreland, Central Oman Mountains, in: Robertson, A.H.F., Searle, M.P. \& Ries, A.C. (eds.), The Geology and Tectonics of Oman Region. Geological Society, London, Special Publication, v. 49, p. 397418.

Boudier, F., Ceuleneer, G. and, Nicolas, A., 1988, Shear zones, thrusts and related magmatism in the Oman ophiolite: Initiation of thrusting on an oceanic ridge, Tectonophysics, v. 151, p. 275296.

Boudier, F., Bouchez, J. L., Nicolas, A., Cannat, M., Ceuleneer, G., Misseri, M. and Montigny R., 1985, Kinematics of oceanic thrusting in the Oman ophiolite: model of plate convergence, Earth and Planetary Science Letters, v. 75, p. 215-222.

Breton, J.-P., Béchennec, F., Le Métour, J., Moen-Maurel, L., and Razin, P., 2004, Eoalpine (Cretaceous) evolution of the Oman Tethyan continental margin: insights from a structural field study in Jabal Akhdar (Oman Mountains), GeoArabia, v. 9, n. 2.

Brun, J.-P., and Cobbold, P., 1980. Strain heating and thermal softening in continental shear zones: a review, Journal of Structural Geology. v. 2, p. 149-158.

Burov, E., 2011. Rheology and strength of the lithosphere, Marine and Petroleum Geology, v. 28, n. 8, p. 1402-1443. 
Ceuleneer, G., Nicolas, A., and Boudier, F., 1988, Mantle flow patterns at an oceanic spreading centre: The Oman peridotites record, Tectonophysics, v. 151, p. 1-26.

Chauvet, F., Dumont T., and Basile C., 2009, Structures and timing of Permian rifting in the central Oman Mountains (Saih Hatat), Tectonophysics, v. 475, p. 563-574.

Cluzel, D., Aitchison, J .C. and Picard, C., 2001, Tectonic accretion and underplating of mafic terranes in the Late Eocene intraoceanic fore-arc of New Caledonia (Southwest Pacific): geodynamic implications. Tectonophysics, v. 340, p. 23-59.

Dewey, J. F., 1976, Ophiolite obduction, Tectonophysics, 31, 93-120.

Duprat-Oualid S., Yamato P. and Pitra P., 2013, Major role of shear heating in intracontinental inverted metamorphism: Inference from a thermo-kinematic parametric study, Tectonophysics. v. 608 , p. $812-831$.

Duretz, T., Gerya, T. V., Kaus, B. J. P., and Andersen T. B., 2012, Thermomechanical modeling of slab eduction, Journal of Geophysical Research, v. 117, p. B08411, 17PP, doi:10.1029/2012JB009137

Forbes, G. A., Jansen, H. S. M., Schreurs, J., Sharikat Tanmiyat Naft `Uman, 2010, Lexicon of Oman : subsurface stratigraphy : reference guide to the stratigraphy of Oman's hydrocarbon basins. Gulf PetroLink, Manama, Bahrain.

Fournier, M., C. Lepvrier, P. Razin, and L. Jolivet, 2006, Late Cretaceous to Paleogene postobduction extension and subsequent Neogene compression in the Oman Mountains, GeoArabia, v. 11, p. $17-40$. 
Gerya, T. V., Stoeckhert, B., Perchuk, A. L. (2002) Exhumation of high-pressure metamorphic rocks in a subduction channel - a numerical simulation. Tectonics, 21, Article Number: 1056.

Gerya, T. V., and Yuen, D. A., 2003, Characteristics-based marker-in-cell method with conservative finite-differences schemes for modeling geological flows with strongly variable transport properties: Physics of the Earth and Planetary Interiors, v.140, n. 4, p. 293-318.

Glennie, K. W., Boeuf, M. G. A., Hughes-Clarke, M. W., Moody-Stuart, M., Pilaar, W. F. H., Reinhardt, B. M., 1974. Geology of the Oman Mountains (Parts 1, 2 and 3). The Hague, Martinus Nijhoff, Verhandelingen Koninklijk Nederlands Geologie en Mijnbouw Genootschap, v. 31 .

Godard, M., Dautria, J.-M., Perrin, M., 2003. Geochemical variability of the Oman ophiolite lavas: Relationship with spatial distribution and paleomagnetic directions. Geochemestry Geophysics. Geosystems, v.4.

Gnos, E., 1998, Peak metamorphic conditions of garnet amphibolites beneath the Semail ophiolite: implications for an inverted pressure gradient, International Geology Review, v. 40, p. 284-304.

Gomez-Rivas, E., Bons, P. D., Koehn, D., Urai, J. L., Arndt, M., Virgo, S., Laurich, B., Zeeb, C., Stark, L., Blum, P., 2014, The Jabal Akhdar dome in the Oman Mountains: Evolution of a dynamic fracture system, American Journal of Science, v. 314, p. 1104-1139.

Gray, D. R., Miller, J. Mc., Gregory, R. T. \& Foster, D. A., 2004, Transition from subduction- to exhumation- related fabrics in glaucophane-bearing eclogites, Oman: evidence from relative fabric chronology and ${ }^{40} \mathrm{Ar}^{-39} \mathrm{Ar}$ ages, Tectonophysics, v. 389, p. 35-64. 
Gray, D. R., and Gregory, R. T., 2000, Implications of the structure of the Wadi Tayin metamorphic sole, the Ibra-Dasir block of the Samail ophiolite, and the Saih Hatat window for late stage extensional ophiolite emplacement, Oman, Marine Geophysical Researches, v. 21, p 211-277.

Gurnis, M., Hall, C., Lavier, L., 2004, Evolving force balance during incipient subduction, Geochemistry, Geophysics, Geosystems, v. 5, Q07001, 31 pp.

Hacker, B. R., 1990, Simulation of the metamorphic and deformational history of the metamorphic sole of the Oman ophiolite, Journal of Geophysical Research, v. 95, p. 4895-4907.

Hacker, B. R., 1991, The role of deformation in the formation of metamorphic field gradients: ridge subduction beneath the Oman ophiolite, Tectonics, v. 10, p. 455-473.

Hacker, B. R., 1994, Rapid emplacement of young oceanic lithosphere: Argon geochronology of the Oman ophiolite, Science, v. 265, p. 1563-1565.

Hacker, B. R., Mosenfelder, J.L., and Gnos, E., 1996, Rapid emplacement of the Oman ophiolite: Thermal and geochronologic constraints, Tectonics, v. 15, pp. 1230-1247.

Jamieson, R. A., 1986, P-T paths from high temperature shear zones beneath ophiolites, Journal of Metamorphic Geology, v. 4, p. 3-22.

Lagabrielle, Y., Chauvet, A., Ulrich, M., and Guillot, S., 2013, Passive obduction and gravitydriven emplacement of large ophiolitic sheets: The New Caledonia ophiolite (SW Pacific) as a case study? Bulletin de la Société Géologique de France, v. 184, n. 6, p.545-556. 
Le Mee, L., Girardeau, J,. and Monnier, C., 2004, Mantle segmentation along the Oman ophiolite fossil mid-ocean ridge, Nature, v. 432, p. 167-172.

Le Métour, J., 1988, Géologie de l'autochtone des Montagnes d'Oman - la fenêtre du Sail Hatat, $\mathrm{PhD}$ thesis, Université Pierre et Marie Curie, Paris 6, $425 \mathrm{p}$.

Le Métour, J., Rabu, D., Tegyey, M., Béchennec, F., Beurrier, M., and Villey, N., 1990, Subduction and obduction: two stages in the Eo-Alpine tectonometamorphic evolution of the Oman Mountains, in: Robertson, A.H.F., Searle, M.P. \& Ries, A.C. (eds.), The Geology and Tectonics of Oman Region. Geological Society, London, Special Publication, v. 49, p. 327-339.

Le Pichon, X., and Nicolas, A., 1981, Thrusting of young lithosphere in subduction zones with special reference to structures in ophiolitic peridotites, Earth and Planetary Science Letters, v. 46, n. 3, p 397-406.

Lippard, S. J., Shelton, A. W., and Gass, I. G., 1986, The ophiolite of Northern Oman: Oxford, Blackwell Scientific Publications, 178 p.

Lus, W.Y., McDougall, I., and Davies, H.L., 2004, Age of the metamorphic sole of the Papuan Ultramafic Belt ophiolite, Papua New Guinea. Tectonophysics, v. 392, p.85-101

Marques, F.O., Nikolaeva, K., Assumpcao, M., Gerya, T.V, Bezerra, F.H.R., do Nascimento, A.F., Ferreira, J.M., 2013, Testing the influence of far-field topographic forcing on subduction initiation at a passive margin. Tectonophysics.

McLeod, C., Lissenberg ,C. J., and Bibby, L. E., 2013, 'Moist MORB' axial magmatism in the Oman ophiolite: evidence against a mid-ocean ridge origin, Geology, G33904. 
Michard, A., Bouchez, J.-L., and Ouazzani-Touhami, M., 1984, Obduction-related planar and linear fabrics in Oman, Journal of Structural Geology, v. 6, n. 1-2, p. 39-49.

Michard, A, Goffé, B., Saddiqi, O., Oberhänsli, R., Wendt, S. A., 1994, Late Cretaceous exhumation of the Oman blueschists and eclogites: a two-stage extensional mechanism, Terra Nova, v. 6, p. 404-413.

Monié, P., and Agard, P., 2009, Coeval blueschist exhumation along thousands of kilometers: Implications for subduction channel processes, Geochemistry Geophysics Geosystems, v.10, n. 7, Q07002.

Moores, E. M., 1982, Origin and emplacement of ophiolites, Reviews of Geophysics, v. 20, n. 4, p. $735-760$.

Nicolas, A., 1989. Structures of ophiolites and dynamics of Oceanic Lithosphere: Netherlands, Kluwer, 367 pp.

Nicolas, A., Boudier, F., Ildefonse, B., and Ball, L., 2000, Accretion of Oman and United Arab Emirates ophiolite - Discussion of a new structural map, Marine Geophysical Researches, v. 21, p. 147-179.

Nolan, S. C., Skelton, P. W., Clissold, B. P., and Smewing, J. D., 1990, Maastrichtian to early Tertiary stratigraphy and palaeogeography of the central and northern Oman Mountains, in: Robertson, A.H.F., Searle, M.P. \& Ries, A.C. (eds.), The Geology and Tectonics of Oman Region. Geological Society, London, Special Publication, v. 49, p. 495-519.

Oxburgh, E. R., 1972, Flake Tectonics and Continental Collision, Nature, v. 239, p. 202-204. 
Pearce, J. A., Alabaster, T., Shelton, A.W., and Searle, M. P., 1981, The Oman Ophiolite as a Cretaceous Arc-Basin Complex: Evidence and Implications, Phil. Trans. R. Soc. Lond., v. 300, n. 1454 , p. 299-317.

Pearce, J. A., Alabaster, T., Shelton, A. W., Searle, M. P., 1981, The Oman ophiolite as a Cretaceous arc-basin complex: evidence and implications. Philosophical Transactions of the Royal Society A: Mathematical, Physical and Engineering Sciences, v. 300, n. 1454, p. 299-317.

Penrose Field Conference. 1972, Ophiolites. Geotimes, v. 17, p. 24-25.

Pubellier, M., Monnier, C., Maury R., and Tamayo, R., 2004. Plate kinematics, origin and tectonic emplacement of supra-subduction ophiolites in SE Asia, Tectonophysics, v. 392, p. 9-36

Rabu, D., 1988, Géologie de l'autochtone des montagnes d'Oman: la fenêtre du Jabal Akhdar - la semelle métamorphique de la Nappe ophiolitique de Samail dans les parties orientale et centrale des Montagnes d'Oman: une revue, $\mathrm{PhD}$ thesis, Université Pierre et Marie Curie, Paris 6, 613 p.

Rabu, D., Le Métour, J., Béchennec, F., Beurrier, M., Villey, M., Degrissac, C.B., 1990, Sedimentary aspects of the Eo-Alpine cycle on the northeast edge of the Arabian Platform (Oman Mountains), in: Robertson, A.H.F., Searle, M.P. \& Ries, A.C. (eds.), The Geology and Tectonics of Oman Region. Geological Society, London, Special Publication, v. 49, p. 49-68.

Ravaut, P., Bayer, R., Hassani, R., Rousset, D., Al Yahya'ey, A., 1997, Structure and evolution of the northern Oman margin: gravity and seismic constraints over the Zagros-Makran-Oman collision zone, Tectonophysics, v. 279, p. 253-280.

Ricou, L. E., 1971, Le croissant ophiolitique péri-arabe, une ceinture de nappes mise en place au crétacé supérieur, Revue de Géographie Physique et de Géologie Dynamique, v. 13, p. 327-50. 
Ricou, L.E., 1994, Tethys reconstructed: plates, continental fragments and their boundaries since 260 Ma from Central America to South-eastern Asia, Geodinamica Acta, v. 7, p. 169-218.

Rioux, M, Bowring, S., Kelemen, P., Gordon, S., Dudás, F., Miller, R., 2012, Rapid crustal accretion and magma assimilation in the Oman-U.A.E. ophiolite: High precision U-Pb zircon geochronology of the gabbroic crust: Journal of Geophysical Research, v. 117, B07201.

Rioux, M., S. Bowring, P. Kelemen, S. Gordon, R. Miller, and F. Dudás, 2013, Tectonic development of the Samail ophiolite: High-precision U-Pb zircon geochronology and Sm-Nd isotopic constraints on crustal growth and emplacement, Journal of Geophysical Research Solid Earth, v. 118, p. 2085-2101.

Saddiqi, O., Michard, A., Goffé, B., Poupeau, G. and Oberhänsli, R., 2006, Fission-track thermochronology of the Oman Mountains continental windows, and current problems of tectonic interpretation. Bulletin of the French Geological Society, v. 177, p. 127-134.

Searle, M. P., 2007., Structural geometry, style and timing of deformation in the Hawasina window, Al Jabal al Akhdar and Saih Hatat culminations, Oman mountains. Geoarabia, v. 12, p. 99-130.

Searle, M. P., Warren, C. J., Waters, D. J., and Parrish, R. R., 2004, Structural evolution, metamorphism and restoration of the Arabian continental margin, Saih Hatat region, Oman Mountains, Journal of Structural Geology. v. 26, p. 451-473.

Searle, M. P., and Cox J., 1999, Tectonic setting, origin, and obduction of the Oman ophiolite, GSA Bulletin, v. 111 no. 1 p. 104-122. 
Searle, M. P., and Malpas, J., 1980, Structure and metamorphism of rocks beneath the Semail Ophiolite of Oman and their significance in ophiolite obduction, Transactions of the Royal Society of Edinburgh. Earth and Environmental Science. v. 71, pp. 247-262

Shervais, J. W., 2001, Birth, Death, and Resurrection: The Life Cycle of Suprasubduction Zone Ophiolites, Geochemistry, Geophysics, Geosystems, v. 2, 2000GC000080.

Stern, R.J., 2004, Subduction initiation: Spontaneous and induced: Earth and Planetary Science Letters, v. 226, p. 275-292.

Thielmann, M., Kaus, B.J.P., 2012, Shear heating induced lithospheric localization: does it result in subduction? Earth and Planetary Science Letters. v. 359-360. p. 1-13.

Tilton, G. R., Hopson, C. A., Wright, J. E., 1981, Uranium-Lead Isotopic Ages Of The Samail Ophiolite, Oman, With Applications To Tethyan Ocean Ridge Tectonics, Journal of Geophysical Research, v. 86, p.2763-2775.

Toth, J., and Gurnis, M., 1998, Dynamics of subduction initiation at pre-existing fault zones, Journal of Geophysical Research, v. 103, n. B8, p.18,053-18,067.

Warburton, J., Burnill, T.J., Graham, R.H., and Isaac, K.P., 1990, The evolution of the Oman Mountains Foreland Basin, in: Robertson, A.H.F., Searle, M.P. \& Ries, A.C. (eds.), The Geology and Tectonics of Oman Region. Geological Society, London, Special Publication, v. 49, p. 419427.

Warren, C. J., Parrish, R. R., Searle, M. P. and Waters, D. J., 2003, Dating the subduction of the Arabian continental margin beneath the Semail ophiolite, Oman, Geology, v. 31, n. 10, p. 889- 
892.

Warren, C. J., Parrish, R, R., Waters, D. J., and Searle, M. P., 2005, Dating the geologic history of Oman's Semail ophiolite: insights from U-Pb geochronology, Contributions to Mineralogy and Petrology, v. 150, n. 4, p. 403-422.

Warren, C. J. and Waters, D. J., 2006, Oxidized eclogites and garnet-blueschists from Oman: PT path modelling in the NCFMASHO system, Journal of Metamorphic Geology, v. 24, n. 9, p. 783-802.

Warren, C. J., Beaumont, C., and Jamieson, R. A., 2008, Formation and exhumation of ultrahigh-pressure rocks during continental collision: Role of detachment in the subduction channel, Geochemistry Geophysics Geosystems, v. 9, n. 4, Q04109.

Yamato P., Agard P., Burov E., Le Pourhiet L., Jolivet L. and Tiberi C., 2007a, Burial and exhumation in a subduction wedge: Mutual constraints from thermomechanical modeling and natural P-T-t data (Sch. Lustrés, western Alps), Journal of Geophysical Research, v. 112, B07410, doi: 10.1029/2006JB004441

Yamato, P., Agard, P., Goffé, B., De Andrade, V., Vidal, O., and Jolivet, L., 2007b, New, highprecision $\mathrm{P}-\mathrm{T}$ estimates for Oman blueschists: implications for obduction, nappe stacking and exhumation processes, Journal of Metamorphic Geology, v. 25, p. 657-682.

Yamato P., Burov E., Agard P., Le Pourhiet L. and Jolivet L., 2008, HP-UHP exhumation during slow continental subduction: Self-consistent thermodynamically and thermomechanically coupled model with application to the Western Alps, Earth and Planetary Science Letters, 271, p. 63-74 


\section{FIGURE CAPTIONS}

Figure 1. Geological setting of the Semail ophiolite (Oman) and associated petrological data. A) Simplified geological map highlighting the dimensions of the ophiolitic nappe and the location of high pressure (HP) units. B) Interpretative cross section through the ophiolite and the metamorphic dome of Muscat. 4 symbols (filled square, white square, white star and black star) indicate continental units of decreasing metamorphic grade. C) Conceptual model of emplacement of oceanic units atop the continental margin. The four symbols correspond to those used in the above panel. D) Compilation of thermobarometric and geochronological data related to the continental margin metamorphism. The four pressure-temperature paths correspond to the symbols used in above panels.

Figure 2. Initial model configuration. The upper panel (A) represents focuses on the transition between the continental plate and the oceanic plate. The lower panel (B) depicts the entire model domain (the red rectangle indicates the location of A). Different colors symbolize the lithologies used in the model (see palette). The whites contours denotes the thermal structure, isotherms are plotted at each $200^{\circ} \mathrm{C}$ increment. The symbol $\gamma$ denotes the gradient of oceanic plate thermal age. Internal time-dependent velocity boundary conditions are imposed along lithospheric columns $(0<\mathrm{y}<80 \mathrm{~km})$ located at $\mathrm{x}=1000 \mathrm{~km}$ and $\mathrm{x}=3000 \mathrm{~km}$ (c.f. arrows). The abbreviations U.C., L.C., Lit., Ast. and Serp., respectively correspond to upper crust, lower crust, lithospheric, asthenospheric and serpentinized. 
Figure 3. Temporal evolution of the model starting from intra-oceanic subduction to the domal exhumation of continental material beneath the overlying ophiolite. The colored stars denote material points used to trace the P-T evolution in the continental margin. The red dot corresponds to a tracer located in the oceanic crust, whose P-T evolution is represented by the red dashed line. The color panel is similar to Figure 2.

Figure 4. Ophiolite structure and P-T paths of material tracers for varying amount of bulk shortening $(d x)$. The compositional field is displayed after $30 \mathrm{My}$ (10 My of compression at $V_{\text {comp }}$ and 20 My of extension). The amount of bulk shortening controls both the dimension of the ophiolite and the amplitude of the P-T paths. The thick brown, red, and yellow lines represent the retrograde path for the HP and UHP continental units of the Arabian margin (Fig. 1D). Material fields colors correspond to those employed in Figure 2.

Figure 5. This figure shows sensitivity of the reference model with regard to the rheology of the upper (U.C) and lower crust (L.C.). The strong and weak crustal end-members (A, D) respectively represent dry granulite and wet quartz rheologies [Ranalli, 1995]. Layered models are depicted in panels B and C. The four models were stopped after $25 \mathrm{My}$ of model time (10 My compression + 15 My extension). This figure highlights the importance of a strong felsic crust rheology for ophiolite emplacement (see Figure 2 for color legend).

Figure 6. Location of the temperature anomaly with regard to the ocean-continent transition. Numerical models were run for $d_{O C T}$ varying between $50 \mathrm{~km}(\mathrm{~A}), 100 \mathrm{~km}$ (B, reference model), 
$200 \mathrm{~km}(\mathrm{C})$ and $300 \mathrm{~km}$ (D). The panels depicts material configurations reached after $25 \mathrm{My}$ of model time for each of these models. Color scheme is similar to that employed in Fig. 2.

Figure 7. Importance of the temperature anomaly intensity. Material configuration of three models are depicted after $25 \mathrm{My}$ of model time. Panel A), B), and C) respectively correspond to $\gamma$ values of $0.5 \mathrm{~cm} \cdot \mathrm{yr}^{-1}, 1.0 \mathrm{~cm} \cdot \mathrm{yr}^{-1}$ (reference model) and $2.0 \mathrm{~cm} \cdot \mathrm{yr}^{-1}$. The colors corresponding to material phases are listed in Fig. 2.

Figure 8. Impact of the timing of the compression/extension transition. Material configurations (see Fig. 2 for legend are represented after both compression and extension (15 My at $1 \mathrm{~cm}^{-\mathrm{yr}^{-1}}$ ). Panel A) shows material configuration obtained for $\Delta \mathrm{t}_{\text {comp }}=5 \mathrm{My}$. The reference model $\left(\Delta \mathrm{t}_{\text {comp }}=\right.$ $10 \mathrm{My}$ ) is depicted in panel B). C) shows the model geometry considering $\Delta \mathrm{t}_{\mathrm{comp}}=15 \mathrm{My}$.

Figure 9. The role of far-field extensional kinematic forcing. A) shows the material configuration obtained after $25 \mathrm{My}$ of model time, while no extension was prescribed. B) corresponds to a $\mathrm{V}_{\text {ext }}$ of $0.5 \mathrm{~cm} . \mathrm{yr}^{-1}$ during $30 \mathrm{My}$, while C) underwent $1.0 \mathrm{~cm} \cdot \mathrm{yr}^{-1}$ extension during $15 \mathrm{My}$ (25 My model time, reference model). In C) the model was subjected to $2.0 \mathrm{~cm} . \mathrm{yr}^{-1}$ extension during 7.5 My (17.5 My model time). The color palette is similar to Fig. 2. 


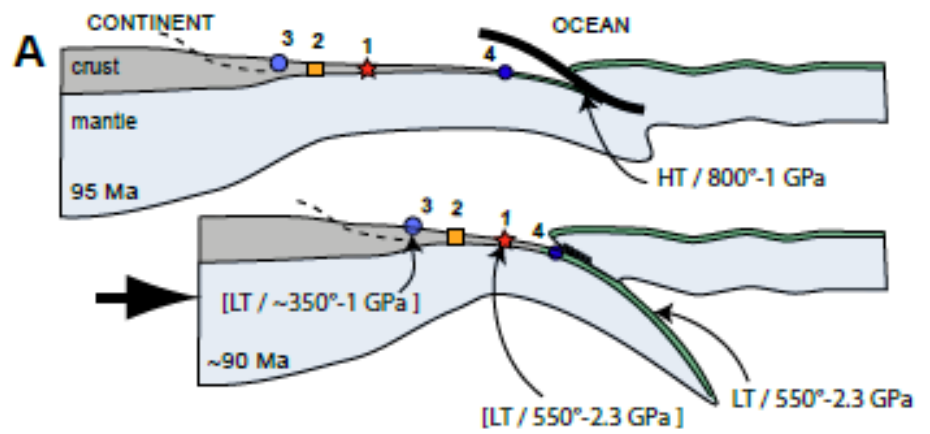

B

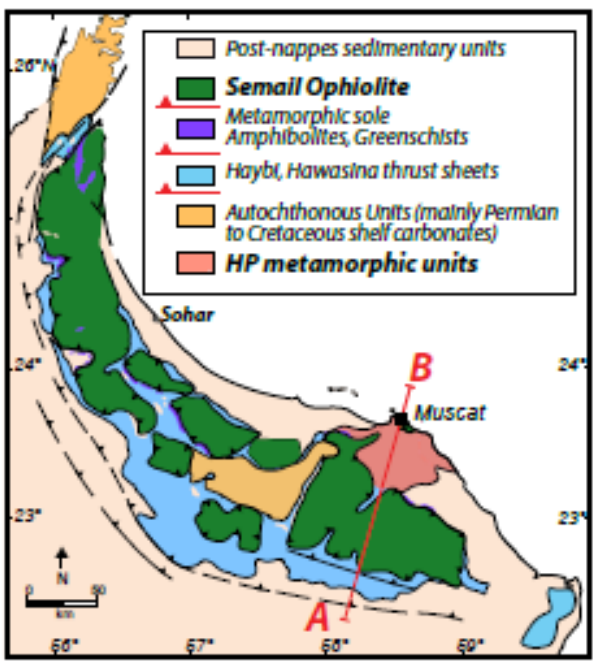

C
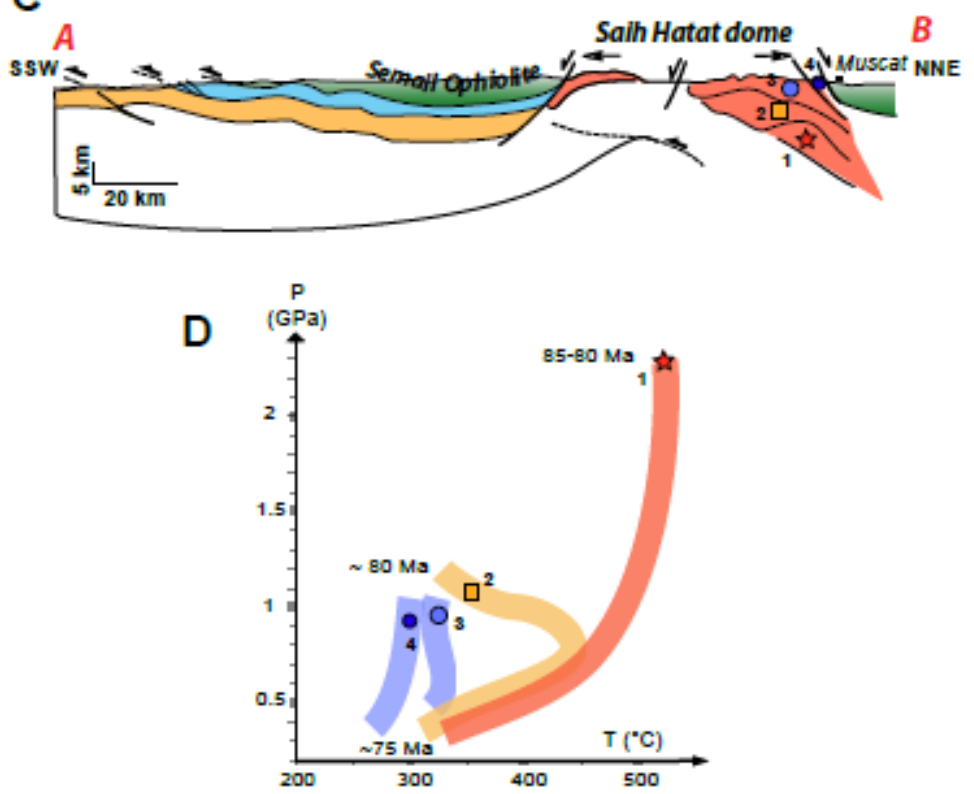

Figure 1 

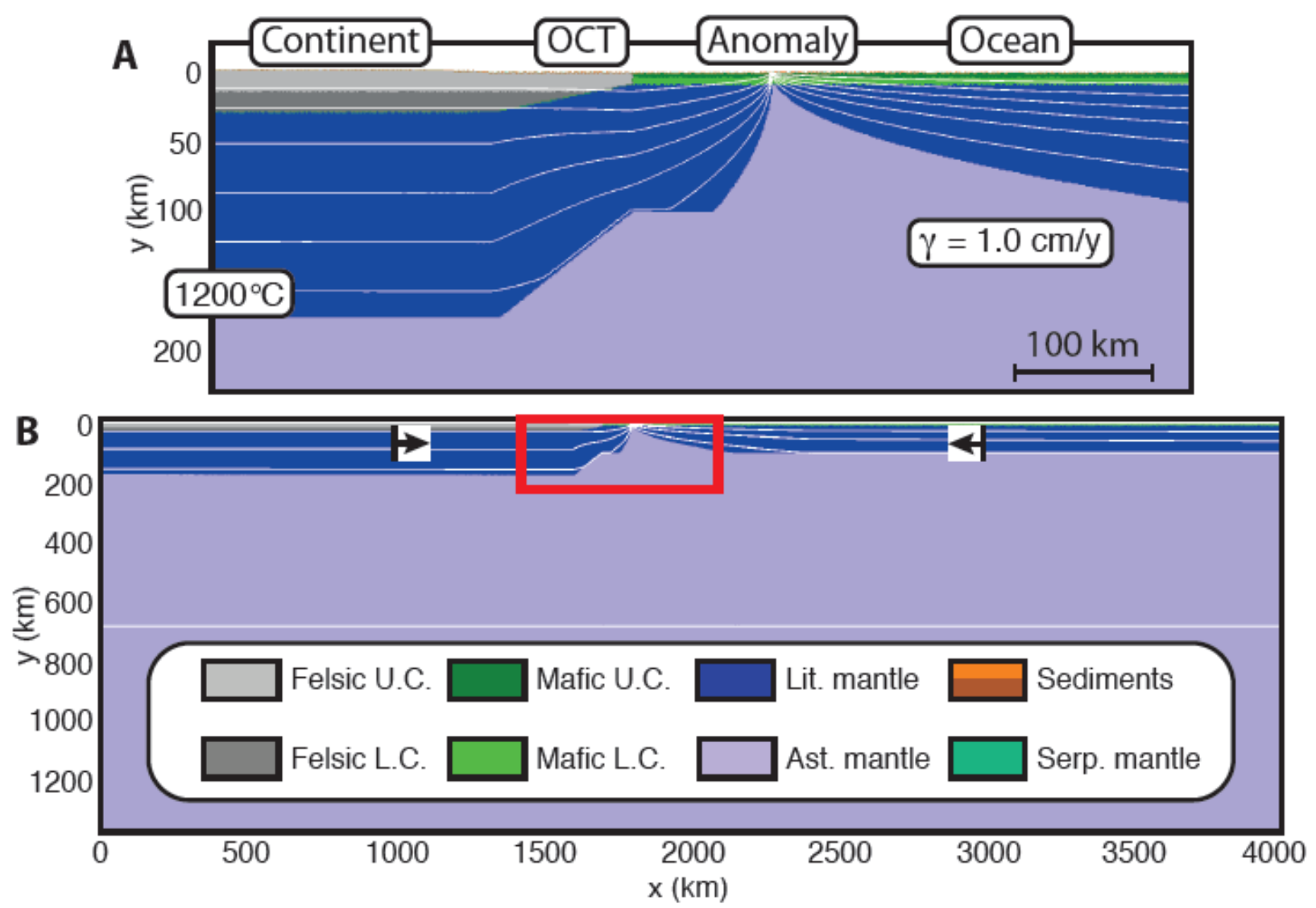

Figure 2 

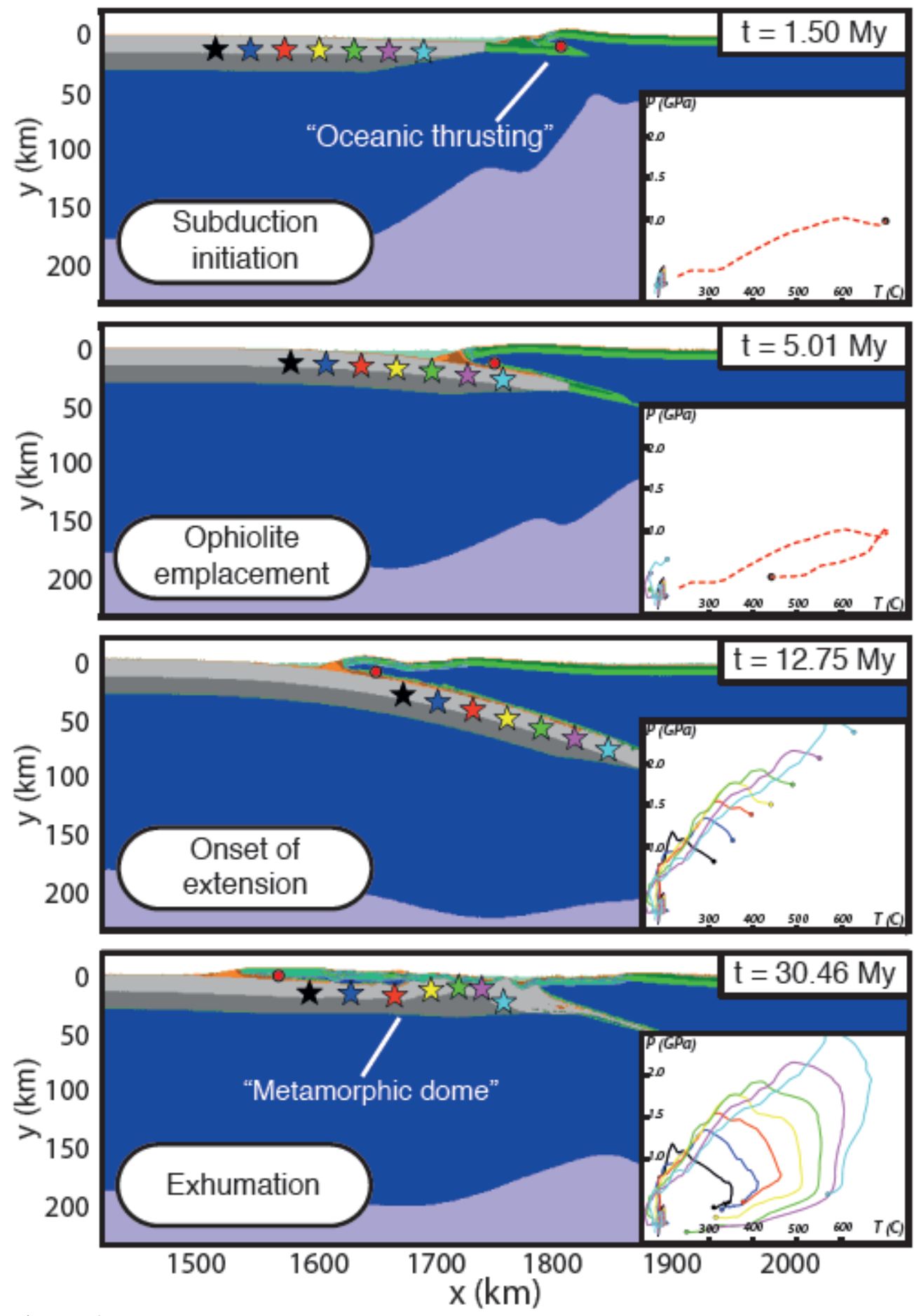

Figure 3 

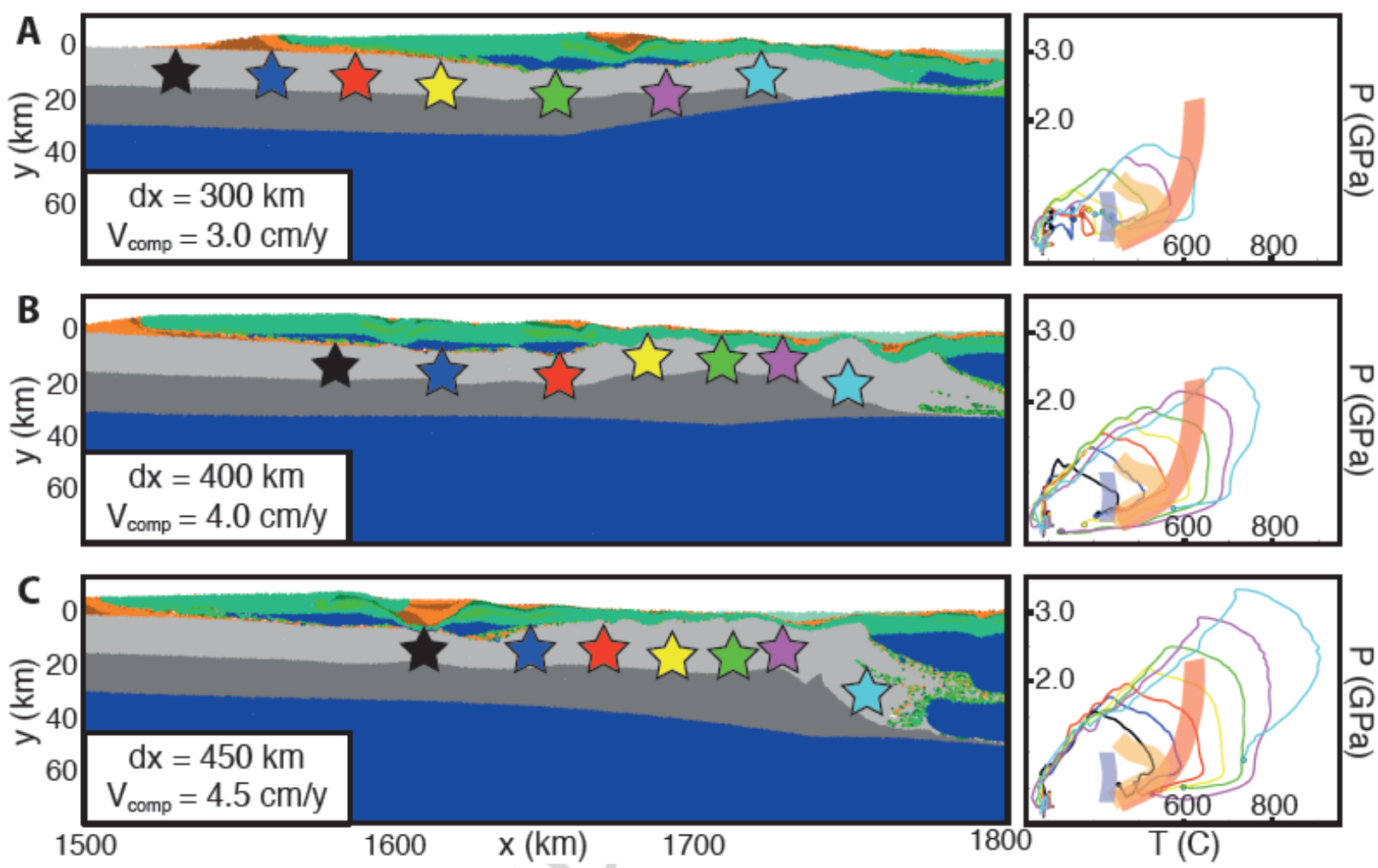

Figure 4 

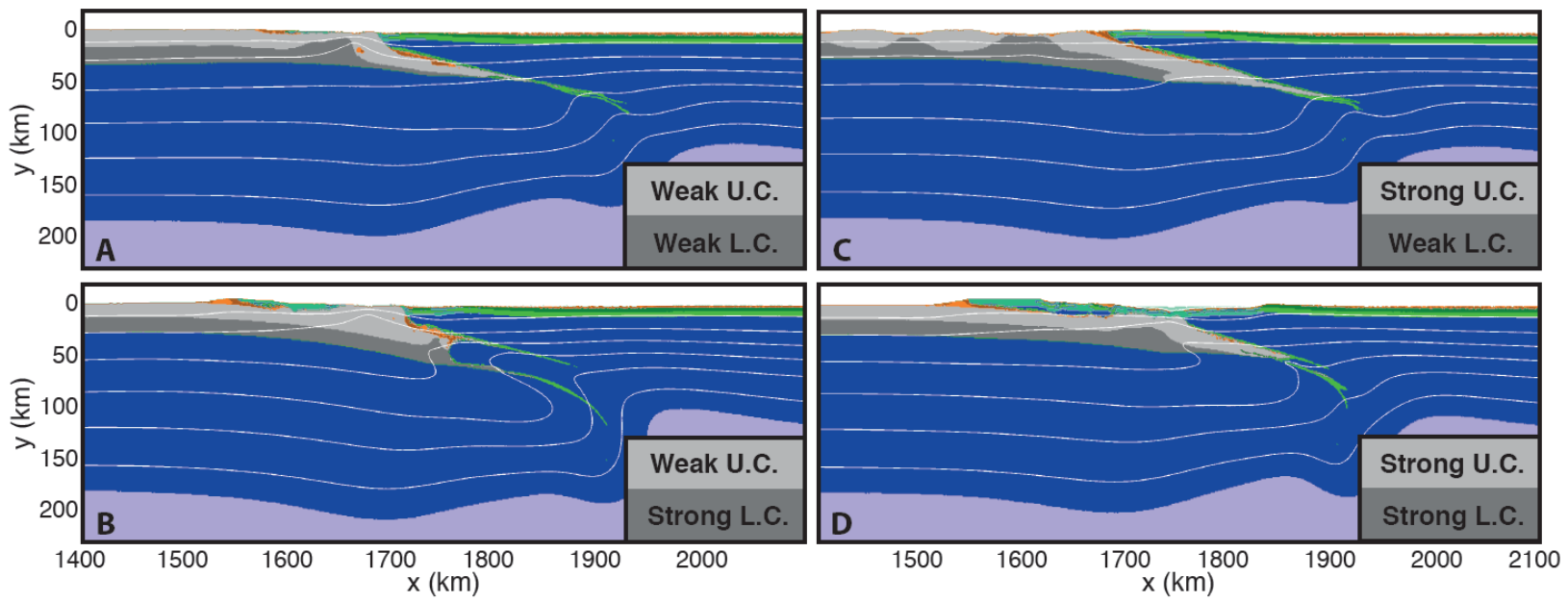

Figure 5 

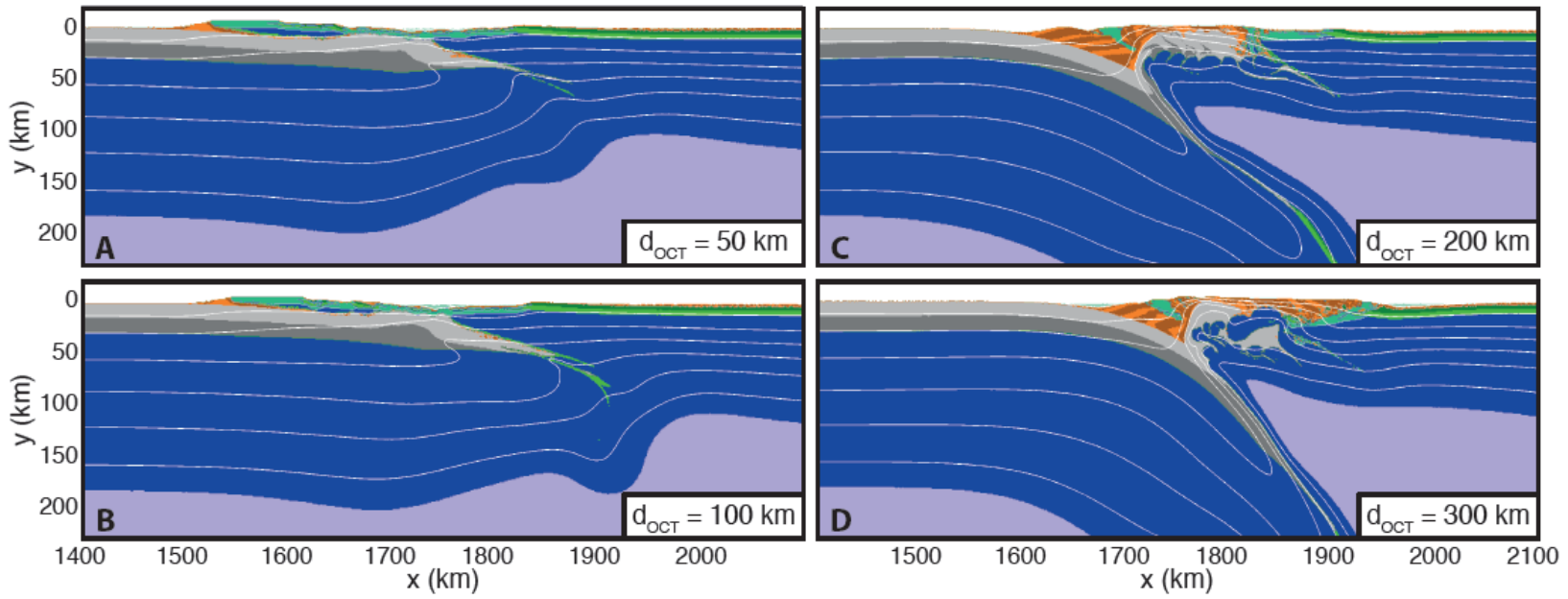

Figure 6 

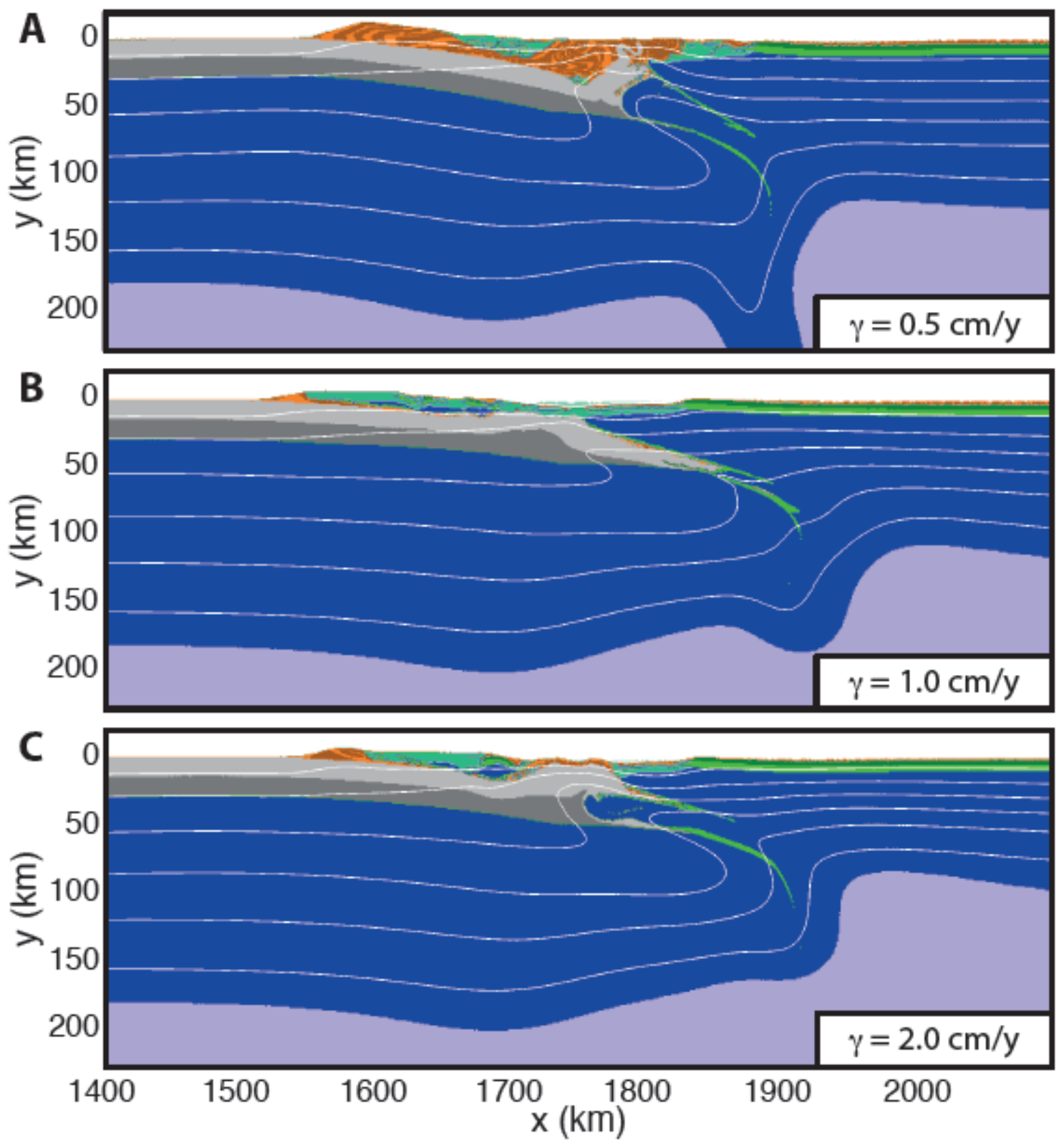

Figure 7 

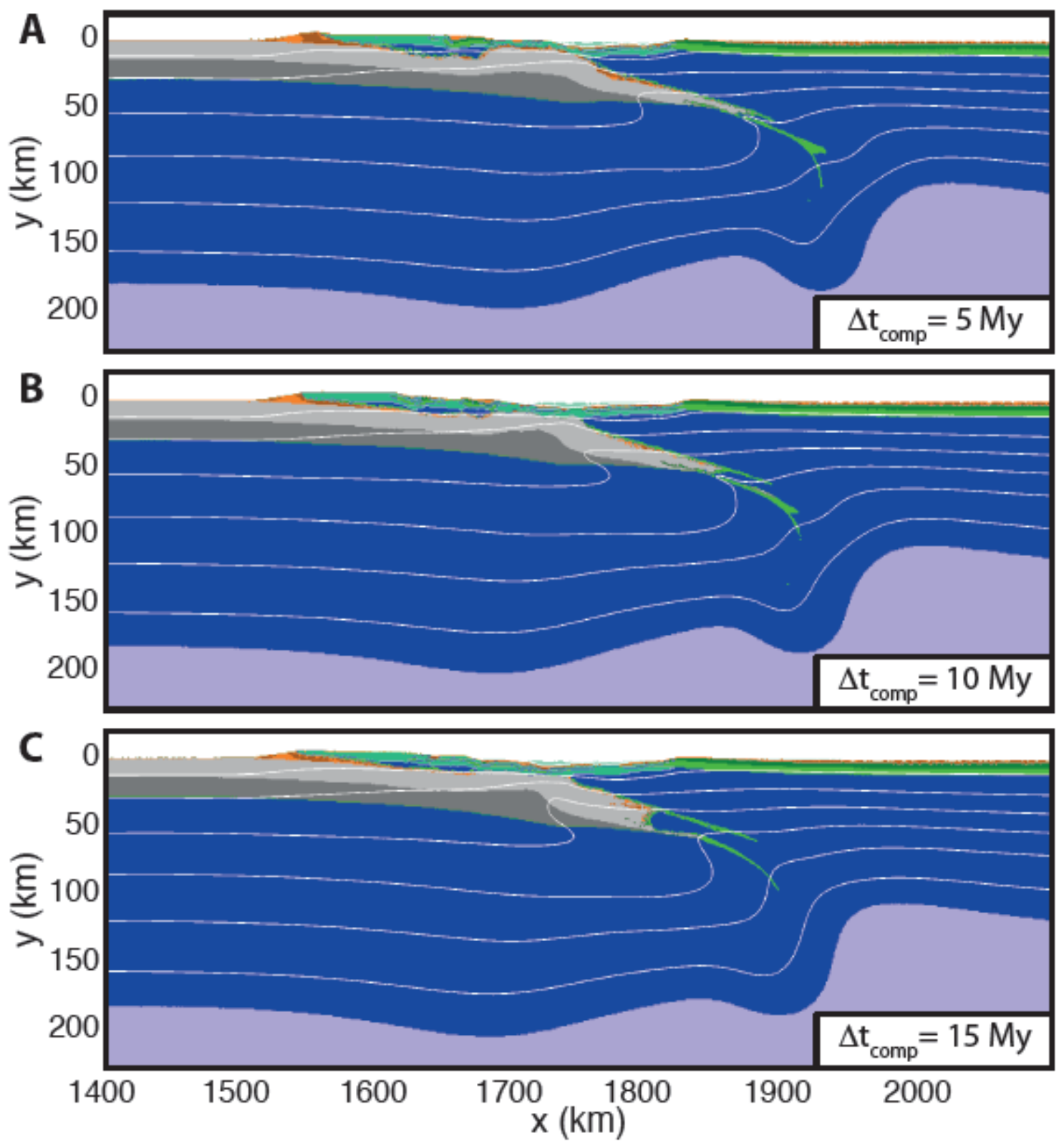

Figure 8 

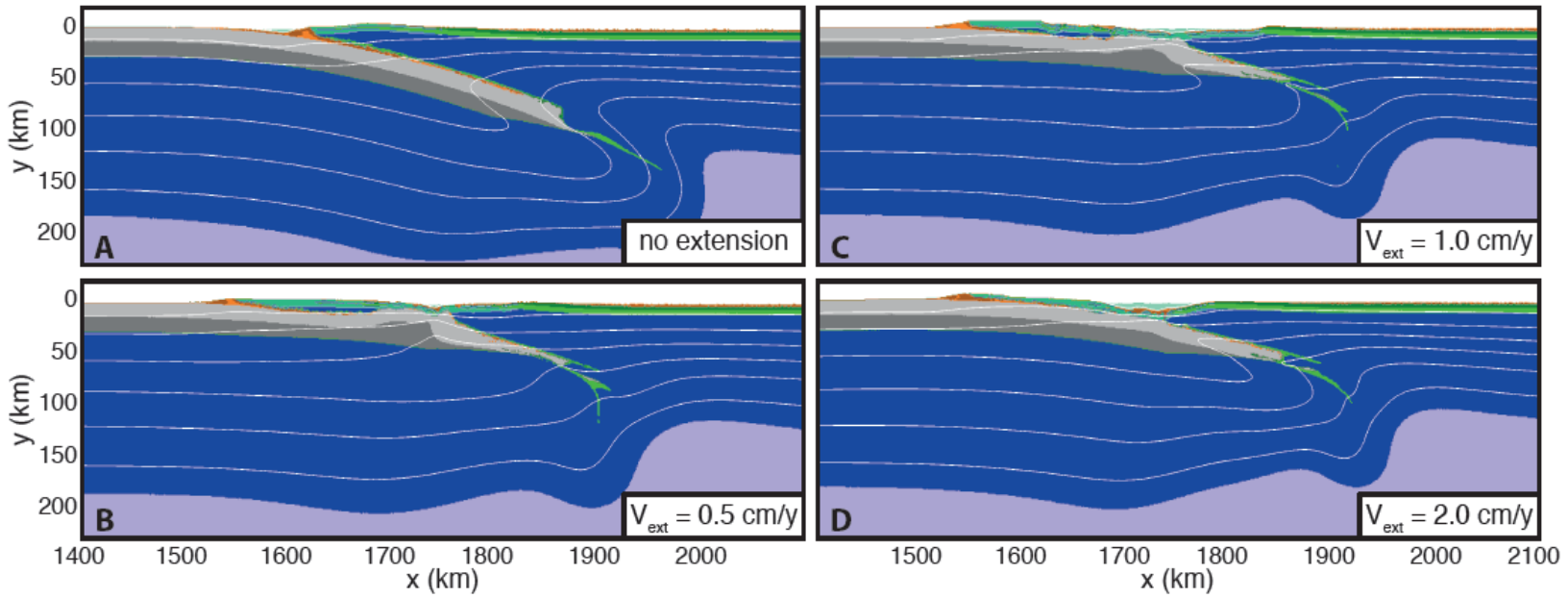

Figure 9 


\section{Material properties}

\begin{tabular}{|c|c|c|c|c|c|c|c|c|c|}
\hline Material & $\begin{array}{c}\mathbf{k}(\mathbf{T}) \\
(\mathbf{W} / \mathbf{m} / \mathbf{K})\end{array}$ & $\begin{array}{c}\mathbf{H}_{\mathbf{r}} \\
\left(\mathbf{W} / \mathbf{m}^{3}\right)\end{array}$ & $\begin{array}{c}\mathbf{C}_{\mathbf{p}} \\
(\mathrm{J} / \mathrm{kg} / \mathbf{K})\end{array}$ & $\sin (\phi)$ & $\begin{array}{c}\mathrm{C} \\
(\mathrm{MPa})\end{array}$ & $\begin{array}{c}\eta_{0} \\
\left(\mathbf{P a}^{\mathrm{n}} \cdot \mathbf{s}\right)\end{array}$ & n & $\begin{array}{c}\mathbf{E}_{\mathbf{a}} \\
(\mathrm{J} / \mathrm{mol})\end{array}$ & $\begin{array}{c}\mathbf{V}_{\mathbf{a}} \\
(\mathrm{J} / \mathrm{bar} / \mathrm{mol})\end{array}$ \\
\hline Felsic U. C. & $\begin{array}{l}0.64+ \\
807 /(\mathrm{T}+77)\end{array}$ & $1.00 \mathrm{e}-6$ & 1000 & 0.45 & 20 & $4.97 \mathrm{e} 20$ & 3.1 & $154 \mathrm{e} 5$ & 1.2 \\
\hline Felsic L. C. & $\begin{array}{l}1.18+ \\
474 /(T+77)\end{array}$ & $0.25 \mathrm{e}-6$ & 1000 & 0.45 & 20 & $4.97 \mathrm{e} 20$ & 3.1 & $154 \mathrm{e} 5$ & 1.2 \\
\hline Mafic U. C. & $\begin{array}{l}0.64+ \\
807 /(\mathrm{T}+77)\end{array}$ & $0.25 \mathrm{e}-6$ & 1000 & 0.00 & 20 & $1.97 \mathrm{e} 17$ & 2.3 & $154 \mathrm{e} 5$ & 0.8 \\
\hline Mafic L. C. & $\begin{array}{l}1.18+ \\
474 /(T+77)\end{array}$ & $0.25 \mathrm{e}-6$ & 1000 & 0.60 & 20 & $4.80 \mathrm{e} 22$ & 3.2 & $238 \mathrm{e} 5$ & 0.8 \\
\hline Lit. mantle & $\begin{array}{l}0.64+ \\
807 /(T+77)\end{array}$ & $2.20 \mathrm{e}-8$ & 1000 & 0.60 & 40 & $3.98 \mathrm{e} 16$ & 3.5 & $532 \mathrm{e} 5$ & 0.8 \\
\hline Ast. mantle & $\begin{array}{l}0.64+ \\
807 /(\mathrm{T}+77)\end{array}$ & $2.20 \mathrm{e}-8$ & 1000 & 0.60 & 40 & $3.98 \mathrm{e} 16$ & 3.5 & $532 \mathrm{e} 5$ & 0.8 \\
\hline Sediments & $\begin{array}{l}0.64+ \\
807 /(\mathrm{T}+77)\end{array}$ & $1.50 \mathrm{e}-6$ & 1000 & 0.15 & 10 & $1.97 \mathrm{e} 17$ & 2.3 & $154 \mathrm{e} 5$ & 0.8 \\
\hline $\begin{array}{l}\text { Serpentinized } \\
\text { mantle }\end{array}$ & $\begin{array}{l}0.64+ \\
807 /(\mathrm{T}+77)\end{array}$ & $2.20 \mathrm{e}-8$ & 1000 & 0.10 & 1 & $3.21 \mathrm{e} 36$ & 3.8 & $890 \mathrm{e} 3$ & 0.8 \\
\hline
\end{tabular}

Table 1. Thermal and mechanical parameters employed in the numerical models: $\mathrm{k}$ is the temperature dependent thermal conductivity, $\mathrm{H}_{\mathrm{r}}$ is the radiogenic heat production, $\mathrm{C}_{\mathrm{p}}$ is the specific heat capacity, $\sin (\phi)$ is the friction coefficient, $\mathrm{C}$ is the cohesion, $\eta_{0}$ is the reference viscosity, $\mathrm{n}$ is the stress exponent, $\mathrm{E}_{\mathrm{a}}$ is the activation energy, and $\mathrm{V}_{\mathrm{a}}$ is the activation volume. 


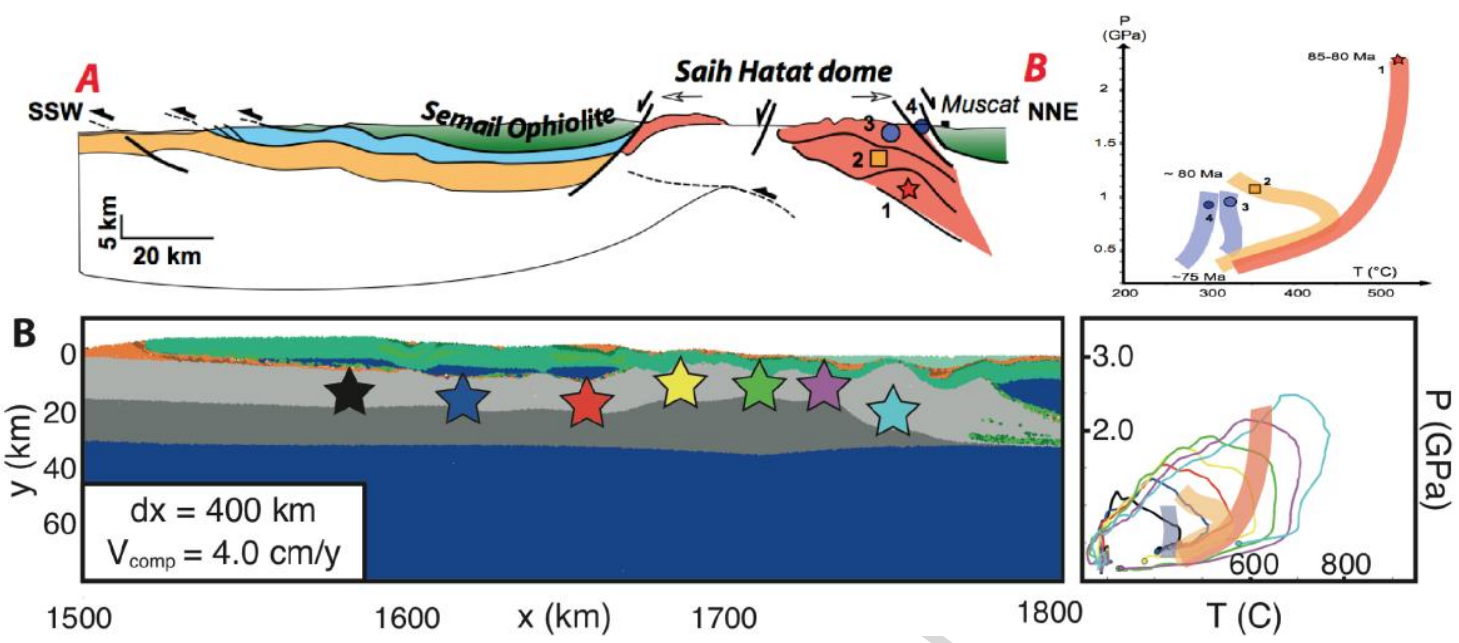

Graphical abstract 


\section{Highlights}

We have set up thermo-mechanical numerical models of obduction

Model allow to reproduce first order geological features of the Oman Ophiolite

Crustal rheology and locus of obduction initiation are first order parameters 